\title{
ЄВРОПЕЙСЬКИЙ СОЮЗ ТА УКРАЇНА: \\ ПЕРСПЕКТИВИ ТА ПРОБЛЕМИ АДАПТАЦІЇ
}

\section{УДК 339.92}

\section{Лікарчук Дар'я Серхї̈вна https://orcid.org/0000-0003-1603-7601 кандидат політичних наук,}

Київський наиіональний університет культури і мистецттв, член-кореспондент Академії політичних наук, Київ, Украӥна, likarchukd@gmail.com

\section{СВРОПЕЙСЬКИЙ СОЮЗ ТА УКРАЇНА: ПЕРСПЕКТИВИ ТА ПРОБЛЕМИ АДАПТАЦІЇ}

У статті аналізуються відносини між Україною та ЄС. Україна вже давно розглядається як важливий політичний партнер Європейського Союзу. ЄС прагне до дедалі більш тісних відносин з Україною, виходячи за межі просто співпраці, до поступової економічної інтеграції та поглиблення політичної співпраці. Аналізуються основні події, що пов'язують Україну та Європейський Союз. Розповідається, як угода про партнерство та співробітництво змінила бачення суспільства про асоціацію, й розкриваються деталі Східної програми ЄС. Паралельно з перспективами відносин між ЄС та Україною, детально аналізується вступ України до ЄС. Подається інформація про поточну ситуацію та аналіз перспектив на майбутнє.

В Україні створено значні законодавчі реформи, які спрямовані на боротьбу 3 корупцією, а також нові спеціалізовані антикорупційні інститути. Робота над впровадженням антикорупційних технологій триває. Деякі з нових українських агентств вже беруть активну участь у боротьбі 3 корупцією. Розвиток західноєвропейської регіональної інтеграції триває, потребуючи аналізу та узагальнення нових явищ. Навіть грунтовний аналіз політичного виміру даного процесу, спроба якого була здійснена в дослідженні, не може дати вичерпної відповіді на багато нагальних питання, адже дискусії про кінцеві цілі інтеграції, в конкретних формах ii здійснення, широті геополітичного охоплення ще не закінчені.

Ключові слова: міжнародні відносини, Україна, інтеграція, Свропейський Союз, реформи, регіональна інтеграція, економіка.

Likarchuk Daria, Candidate of Political Sciences, Kyiv National University of Culture and Arts, Political Science Academy Corresponding Member, Kyiv, Ukraine

The European Union and Ukraine: prospects and problems of adaptation

The article analyzes the relations between Ukraine and the EU. Ukraine has long been seen as an important political partner of the European Union. The EU is striving for ever closer relations with Ukraine, going beyond mere cooperation, gradual 


\section{МІЖНАРОДНІ ВІДНОСИНИ: ТЕОРЕТИКО-ПРАКТИЧНІ АСПЕКТИ ВИПУСК 3 (2019) \\ ISSN (print) 2616-745X; ISSN (online) 2616-7794}

economic integration and deepening political cooperation. The main events that link Ukraine and the European Union are analyzed. The article tells how the Partnership and Cooperation Agreement has changed the vision of the society about the association, and reveals the details of the EU Eastern Program. In parallel with the prospects for EU-Ukraine relations, Ukraine's accession to the EU is analyzed in detail. The author provides information on the current situation and analyses prospects for future.

Ukraine has framed significant legislative reforms, aimed at combating corruption, and founded new specialized anti-corruption institutions. Work on the implementation of anti-corruption technologies is still in a process. Some of the new Ukrainian agencies are already actively involved in the fight against corruption. The development of Western European regional integration continues, requiring analysis and synthesis of new phenomena. Even a thorough analysis of the political dimension of this process, an attempt been made in the study, can not give exhaustive answer to many urgent issues. Since discussions about the ultimate goals of integration, in particular forms of its implementation, the breadth of geopolitical coverage are not yet complete.

Key words: international relations, Ukraine, integration, European Union, reforms, regional integration, economy.

Ликарчук Дарья Сергеевна, кандидат политических наук, Киевский начиональныій университет культуры и искусств, член-корреспондент Академии политических наук, Киев, Украина

\section{Европейский Союз и Украина: перспективы и проблемы адаптации}

В статье анализируются отношения между Украиной и ЕС. Украина уже давно рассматривается как важный политический партнер Европейского Союза. ЕС стремится к все более тесным отношениям с Украиной, выходя за пределы просто сотрудничества, к постепенной экономической интеграции и углубления политического сотрудничества. Анализируются основные события, связывающие Украину и Европейский Союз. Рассказывается, как соглашение о партнерстве и сотрудничестве изменила видение общества об ассоциации, и раскрываются детали Восточной программы ЕС. Параллельно с перспективами отношений между ЕС и Украиной, подробно анализируется вступление Украины в ЕС. Подается информация о текущей ситуации и анализ перспектив на будущее.

В Украине созданы значительные законодательные реформы, направленные на борьбу с коррупцией, а также новые специализированные антикоррупционные институты. Работа над внедрением антикоррупционных технологий продолжается. Некоторые из новых украинских агентств уже активно участвуют в борьбе с коррупцией. Развитие западноевропейской региональной интеграции продолжается, требуя анализа и обобщения новых явлений. Даже основательный анализ политического измерения данного процесса, попытка которого была осуществлена в исследовании, не может дать исчерпывающего ответа на многие насущные 


\section{ЄВРОПЕЙСЬКИЙ СОЮЗ ТА УКРАЇНА: \\ ПЕРСПЕКТИВИ ТА ПРОБЛЕМИ АДАПТАЦІЇ}

вопросы, ведь дискуссии о конечных целях интеграции, в конкретных формах ее осуществления, широте геополитического охвата еще не закончены.

Вступ. У політичному, культурному та торгово-економічному відношеннях Україна та держави ЄС були пов'язані один з одним вже багато століть. У даний час відносини між Україною та ЄС стають більш насиченими та різноманітними.

ЄС займає одне з найважливіших місць в українських економічних аспектах, a саме: торгове, інвестиційне науково-технічне та культурне співробітництво; реалізацію спільних проектів у сферах здійснення гуманітарних програм, безпеки, охорони навколишнього середовища та стратегічного планування.

Напередодні XXI ст. світ, зокрема й Україна та Європа, виявився перед обличчям численних змін й зародженням нових процесів - як зовнішніх, так і внутрішніх. У світлі зростаючого різноманіття світових спільнот й тенденції до глобалізації, піддаються перегляду багато положень, процесів, технологій та явища (Mikhel, 2010, p. 153), що характеризують систему міжнародних відносин, зокрема й один з базових принципів - суверенітет сучасної держави.

Великого значення надається регіональній інтеграції держав i, насамперед, що об'єднується навколо європейських ідей та цінностей. Якщо спочатку йшлося переважно про економічні та технічні елементи взаємодії, то в останньому десятилітті розпочато будівництво стабільного та міцного політичного союзу.

3 новими тенденціями формуються загальні норми в таких сферах, як соціальна політика, імміграція, правосуддя, зовнішня політика, узгоджуються митні правила та питання безпеки. У зв'язку зі зміненою системи міжнародних відносин (Brexit) i новою роллю $\mathrm{CC}$, а саме тому ефективна інтеграція між європейськими політичними інститутами і Україною є особливо важливою.

Аналіз попередніх досліджень та публікацій. Ідея «європейської інтеграції» стала поширеною в 1990-х рp., коли багато незалежних держав проголосили гасло «назад, до Європи», як ефективний політичний курс, під яким розумілося приєднання до всіх європейських інститутів (Європейський парламент, Європейська рада, Європейський центральний банк та Європейський суд аудиторів) (Green Cowles, Dinan, 2004, p. 47). Однак саму по собі дану концепцію навряд чи ми можемо назвати новою, адже більшість дослідників інтеграційних процесів в цілому й Європейського Союзу зокрема, починають відлік 3 першої декади після завершення Другої Світової війни (Marise, 2005, p. 19).

Істотний внесок у вивчення даної проблематики внесли вітчизняні дослідники, серед яких варто виокремити роботи: В. Андрійчук, М. Карлін, А. Киридон, В. Копійка, В. Муравйов, В. Трюхан,

В іноземних джерелах питання розширення СС також отримало досить широке висвітлення. Варто зазначити роботи: В. Баласса, С. Борхадта, Р. Белдвіна, Х. Габріша, Х. Граббе, Ч. Гранта, А. Мерфі, Х. Тіммермана, Е. Хааса, П. Хавліка, С. Хоффмана, С. Евертса. 


\section{МІЖНАРОДНІ ВІДНОСИНИ: ТЕОРЕТИКО-ПРАКТИЧНІ АСПЕКТИ ВИПУСК 3 (2019) \\ ISSN (print) 2616-745X; ISSN (online) 2616-7794}

Мета дослідження. Через аналіз сучасних європейських політичних структур надати характеристику потенціалу взаємин України та Європейського Союзу. Дослідити й оцінити вплив процесу розширення ЄС на розвиток економічних відносин України з країнами-членами Свросоюзу, а також виробити рекомендації щодо коригування зовнішньоекономічної політики України для реалізації політичних та економічних інтересів нашої держави.

Виклад основного матеріалу. В основі Європейського Союзу закладена концепція інтеграції держав. Поняття «інтеграції», зазвичай, трактується як об'єднання рівних за значимістю соціальних елементів у суспільство або організацію - це стосується як фізичних осіб, так і держав (Mikhel, 2010, p. 156).

За процесами, що відбуваються в Західній Європі, уважно стежить весь світ. I це не випадково. Адже Свропейський Союз - один з провідних центрів глобального розвитку, ключовий вузол майбутньої системи глобального управління, політичний феномен величезного значення для світової та європейської політики (Likarchuk, 2016, p. 117). Саме тому значення змін, що постійно відбуваються в європейському регіоні виходить далеко за його межі. Вони надають зростаючий вплив на взаємовідносини Західної Європи з США та Японією, НАТО, ЛАД, державами «третього світу» й на всю систему глобальних економічних та політичних відносин. Від характеру цих змін, їх інтенсивності багато в чому залежать перспективи світового розвитку.

Політичні проблеми західноєвропейської інтеграції займають значну частину співпраці держав-членів ЄС. Формально вони формують так звані другу і третю «опори» Свропейського Союзу (Mikhel, 2010, p. 155), тобто це: питання вдосконалення системи управління Союзу і проведення інституційної реформи; конструювання спільної зовнішньої політики й політики безпеки; набуття спільнотою власної оборонної ідентичності, вибір нових зовнішньополітичних пріоритетів; співпраця в галузі внутрішніх справ i правосуддя. Ці проблеми належать до сфери міждержавного співробітництва держав-членів СС і вельми важкі для узгодження в силу того, що більшість 3 цих питань традиційно належать до компетенції національних адміністрацій, а останні вкрай неохоче прагнуть делегувати їх рішення комунітарним структурам.

Ми вважаємо, що процеси глобалізації та регіоналізації аж ніяк не скасовують поняття «національний інтерес». У міру поглиблення й розширення інтеграційних процесів західноєвропейському регіональному співтовариству все частіше доводиться мати справу з тенденціями, що стали безапеляційною частиною історії: пріоритет національних інтересів та цінностей; збереження специфіки та особливостей окремих держав і їх урядів (Likarchuk, 2017). Тому ми вважаємо, що відбувається певне повернення до політики відстоювання національних інтересів - це реакція західноєвропейських еліт, що виходять 3 під контролю процесу глобалізації. 


\section{ЄВРОПЕЙСЬКИЙ СОЮЗ ТА УКРАЇНА: \\ ПЕРСПЕКТИВИ ТА ПРОБЛЕМИ АДАПТАЦІЇ}

3 іншого боку, процеси політичної інтеграції в західноєвропейському регіоні, безумовно, мають об'єктивний характер. Свропа прагне до набуття своєї політичної ідентичності в умовах глобальної трансформації світоустрою. Крім того, для деяких держав $\mathrm{С} \mathrm{участь} \mathrm{в} \mathrm{інтеграційних} \mathrm{процесах} \mathrm{дозволяє} \mathrm{обійти} \mathrm{певні} \mathrm{межі}$ національного суверенітету, й стати на рівні з провідними державами світу. На нашу думку, саме Німеччина, є природним «осередком» інтеграції, безумовним лідером об'єднання. Саме коли зріс вплив Німеччини в Європі по суті відбулися зміни всієї інтеграційної конструкції Європейського Союзу на рубежі XX-XXI ст. - зараз можна стверджувати, що ЄС відповідає ознакам наддержави, включаючи власну зовнішню політику і військово-політичні структури, блок впевнено рушив на Схід, стартувала інституційна реформа, Європейський Союз став більше стабільним у вирішенні глобальних і регіональних завдань, саме як політична організація.

Цілком очевидно, що і Україна як невід'ємна частина загальноєвропейського простору не може залишатися осторонь від цих процесів. Українська сторона відзначає зростаюче значення зусиль України щодо налагодження партнерства Європейським Союзом, підкресливши, що «курс на інтеграцію з Європою стає одним 3 ключових напрямків української зовнішньої політики» (Mikhel, 2010, p. 156). Дана установка передбачає поглиблене вивчення політичного виміру Європейського Союзу як найбільш динамічного розвиненого «консолідованого ядра» західноєвропейської інтеграції. Для України не байдуже, 3 якою Європою їй доведеться мати справу надалі. Чи стане Європейський Союз: федеративною наддержавою? або вільним союзом націй-держав? або можливо виникне інша форма політичного устрою? Саме від цього буде залежати характер зовнішньополітичної стратегії України щодо найбільшого політичного й економічного партнера - Європейського Союзу.

Особливе значення з точки зору перспектив подальшого партнерства між двома сторонами має формування спільної зовнішньої політики та політики безпеки $€ С$ й оперативної складової - європейської політики в галузі безпеки і оборони. Набуття Європейським Союзом, поряд з економічним, також військово-політичного виміру відкриває можливості для взаємодії між Україною і ЄС 3 широкого кола питань світової політики (Pierson, 2004, p. 95). Свросоюз може стати природним партнером України в пошуках спільних відповідей на нові загрози i виклики європейської та міжнародної безпеки, шляхом вироблення параметрів майбутніх антикризових операцій за участю сил швидкого реагування $Є С$.

Поряд зі спільним врегулюванням криз, порядок денний діалогу між Україною і СС може бути успішно доповнений іншими питаннями, актуальними для безпеки європейського континенту, наприклад, проблематикою стратегічної стабільності і протиракетної оборони, питаннями роззброєння та регіональної безпеки. Варто звернути увагу й на думку українського науковця та політика Безсмертного Романа Петровича, він зазначає: «Теза про війну у Європі поки 


\section{МІЖНАРОДНІ ВІДНОСИНИ: ТЕОРЕТИКО-ПРАКТИЧНІ АСПЕКТИ

що сприймається i розуміється хіба, що тільки на рівні якоїсь частини істеблішменту, окремих осіб. Підтвердженням цьому $є$ й той відомий нідерландський референдум, на якому було висловлено заперечення щодо Асоціації України з СС 6 квітня 2016 р.» (Bezsmertnyi, 2018, p. 17).

Тенденція до посилення політичного діалогу між Україною і $Є С$ в майбутньому буде наростати, однак не можна не бачити «меж можливого» в розвитку цього процесу. Виникає ряд об'єктивних і суб'єктивних обмежень, що ускладнюють становлення українсько-європейського партнерства (Mikhel, 2010, p. 154).

Зважаючи на останні події, варто відзначити, що незважаючи на існування різних теоретичних концепцій, можна констатувати, що в даний час цілісної $\mathrm{i}$ повноцінної теорії міжнародної економічної інтеграції не існує. Більш того, ще не знайдено вичерпну відповідь на питання про те, в чому полягають конкретні переваги держави, яка долучається в інтеграційне об'єднання, в порівнянні 3 державою, що не входить до нього. У зв'язку з цим аналіз процесу адаптації нових держав до умов діяльності ЄС може сприяти створенню необхідної бази для вивчення позитивного і негативного впливу розширення інтеграційного об'єднання на економічний розвиток держав-учасників і «третіх держав». Використання цього досвіду допоможе запобігти вчиненню помилок при зближенні нашої держави з Свросоюзом та оптимізувати для України наслідки долучення до СC (Likarchuk, 2017).

Ми вважаємо, що ефективну систему економічних та політичних зв'язків України з Свросоюзом необхідно будувати з урахуванням сформованих економічних відносин та перспектив подальшого розширення СС.

Основні проблеми сучасного етапу розширення $\mathrm{CC}$ полягають у невідповідності держав критеріям членства та необхідності проведення великомасштабних реформ абсолютно у всіх сферах суспільного життя. Процес розширення ЄС ускладнюється тим, що в середньостроковій перспективі нові держави зможуть стати лише реципієнтами фінансової допомоги, що розподіляється серед найменш розвинених держав і регіонів СС. У результаті загострюються розбіжності між державами донорами та державами одержувачами фінансової допомоги із загального бюджету СС. Незважаючи на введення перехідних періодів для нових держав-учасниць, система розподілу фінансових ресурсів Євросоюзу змінюється: ряд держав «які отримують зараз фінансові кошти перейде в розряд донорів, а тиск на нинішніх платників СС посилиться ще більше» (Mikhel, 2010, p. 157). Складнощі, пов'язані з перерозподілом фінансових ресурсів доповнюються побоюваннями держав-засновників СС щодо небезпеки масштабного припливу робочої сили з нових держав-членів інтеграційного об'єднання.

Формування нової спільної позиції країн-учасниць Євросоюзу з питання вільного переміщення робочої сили наштовхується на труднощі. Незважаючи 


\section{ЄВРОПЕЙСЬКИЙ СОЮЗ ТА УКРАЇНА: ПЕРСПЕКТИВИ ТА ПРОБЛЕМИ АДАПТАЦІЇ}

на несприятливу демографічну ситуацію, багато старих країн СС висловлюють занепокоєння з приводу масового припливу іноземних робітників, оскільки це може посилити конкуренцію місцевим працівникам, загострити проблему безробіття $\mathrm{i}$ істотно збільшити тиск на соціальні фонди старих держав-учасників СС.

Враховуючи точку зору Міхеля Д. О., варто зазначити, що аналіз попередніх етапів розширення ЄС показав, що масової міграції з нових держав в державизасновники ЄС не відбудеться (Mikhel, 2010,p. 153). Але часткова міграція вплине на рівень заробітної плати та можливості працевлаштування низькокваліфікованої робочої сили, чим й схвильовані сьогодні європейські політичні інститути. Посилення конкуренції серед працівників робітничих спеціальностей може послужити додатковим стимулом для громадян держави-засновники СС в отриманні освіти та підвищенні своєї кваліфікації.

У той же час, держави-засновники Євросоюзу починають активніше включатися в конкурентну боротьбу за залучення кваліфікованих фахівців. У процесі дослідження було встановлено, що в сфері міграції робочої сили сформувалось кілька тенденцій, які походять від європейських політичних інститутів: $з$ одного боку, обмежується загальний масштаб припливу іммігрантів, зіншого - починаються створюватися умови для залучення іноземних висококваліфікованих кадрів.

Ми вважаємо, що сучасна Україна - це європейська держава, яка прагне до того, щоб зайняти відповідне ії потенціалу місце в європейській і світовій політиці, тому в ході формування своєї зовнішньої політики Україна приділяє значну увагу відносинам з європейськими політичними інститутами. У той же час й європейські інститути усвідомлюють, що існує багато питань, які становлять спільний інтерес та вимагають, як мінімум, взаємодії, якщо не активної співпраці з Україною: економіка, зовнішня безпека, наука та освіта. Але в даному випадку варто врахувати точку зору українського науковця Семчинського К. В., який відзначив: «Не можна наразі виключати такого розвитку подій, за якого Росія в своєму прагненні перешкодити розширенню СС і НАТО на Схід...» (Semchynsky, 2018, p. 64).

Висновки. Дана всебічна оцінка взаємин між Україною та європейськими політичними інститутами як в ретроспективі, так і на сучасному етапі історичного розвитку дає змогу оцінити можливості України, щодо свого потенціалу.

Розвиток західноєвропейської регіональної інтеграції триває, потребуючи аналізу та узагальнення нових явищ. Навіть грунтовний аналіз політичного виміру даного процесу, спроба якого була здійснена в дослідженні, не може дати вичерпної відповіді на багато нагальних питання, адже дискусії про кінцеві цілі інтеграції, в конкретних формах іiі здійснення, широті геополітичного охоплення далеко ще не закінчені.

Осмислення еволюційної сутності процесу становлення політичної архітектури нової Свропи, від якого залежать можливості України впливати 


\section{МІЖНАРОДНІ ВІДНОСИНИ: ТЕОРЕТИКО-ПРАКТИЧНІ АСПЕКТИ

на формування парадигми загальноєвропейського і світового розвитку в XXI ст. й більш цілеспрямовано виробляти свою політичну стратегію щодо $\mathrm{CC}$, має набути практичного значення і стати об'єктом уваги сучасної політичної науки.

Звідси ж випливає ще одна специфіка політичної науки - сприяти визначенню можливостей реалізації закономірностей розвитку західноєвропейського інтеграційного співтовариства в чітко визначених умовах, формуванню потужної зони політичної стабільності та економічного зростання на великому євразійському просторі.

У контексті вступу нових держав до ЄС найбільш важливим питанням $€$ взаємини України та Євросоюзу. На нашу думку, триватиме продовження енергетичного діалогу, співпраці в інвестиційній сфері, гармонізація законодавства, а також вдосконалення технічних та екологічних норм і стандартів. Значну роль для успішної інтеграції України до спільного європейського економічного простору буде відігравати: розширення доступу до ринку СС та вироблення ефективних механізмів врегулювання суперечностей з питань антидемпінгу; оптимізація митного режиму; реалізація спільних з СС проектів у сфері технологічного співробітництва.

\section{References:}

1. Bezsmertnyi, R. (2018). 'Ukrainsko-rosiiska viina: heopolitychnyi konteks' [The war between Ukraine and Russia: a geopolitical context]. Mizhnarodni vidnosyny: teoretyko-praktychni aspekty [International Relations: Theory and Practical Aspects], Vol. 2, pp. 13-21. DOI: https://doi.org/10.31866/2616-745x.2.2018.133325.

2. Frazer, C. (2005). The future of Europe. Integration and enlargement. London: Rutledge.

3. Green Cowles, M., Dinan, D. (2004). Developments in the European Union. London: Palgrave Macmillan.

4. Likarchuk, D. (2016). 'Osnovni sposoby vyrishennia parlamentskykh konfliktiv u suchasnii Ukraini' [Basic solutions parliamentary conflicts in modern Ukraine]. Suspilno-politychni protsesy [Public political processes], no. 3, pp. 107-155.

5. Likarchuk, D. (2017). 'Faktor efektynnosti mekhanizmu politychnoi komunikatsii' [The factor of the effectiveness of the mechanism of political communication]. Social and Human Sciences. Polish-Ukrainian scientific journal, [online], Vol. $04 \quad$ (16). Available at: <https://spsciences.io.ua/s2621819/likarchuk_daria_2017._the_factor_of_the_effectiveness_of_the_ mechanism_of_political_communication._social_and_human_sciences._polishukrainian_scientific_journal_04_16_> [Accessed at 28 October 2018].

6. Marise, C. (2005). The enlargement of European Union. New-York: Oxford Universiti Press. 


\section{ЄВРОПЕЙСЬКИЙ СОЮЗ ТА УКРАЇНА: \\ ПЕРСПЕКТИВИ ТА ПРОБЛЕМИ АДАПТАЦІЇ}

7. Mikhel, D. (2010). 'Kopenhahenski kryterii yak chynnyky rozbudovy demokratychnykh protsesiv ta nablyzhenosti do yevropeiskoho rivnia zhyttia v Ukraini' [Copenhagen criteria as factors of the development of democratic processes and proximity to the European standard of living in Ukraine]. Naukovi pratsi. Politolohiia [Scientific works. Politology], issue 137, Vol. 149, pp. 153-157.

8. Pierson, P. (2004). Politics in Time: History, Institutions, and Social Analysis. Princeton, NJ: Princeton University Press.

9. Semchynskyi, K. (2018). 'Osoblyvosti prymyrennia i myrobudivnytstva v umovakh zamorozhenykh konfliktiv na postradianskomu prostori' [The features of reconciliation and peace building in conditions of frozen conflicts on the post-Soviet territory]. Mizhnarodni vidnosyny: teoretyko-praktychni aspekty [International Relations: Theory and Practical Aspects], Vol. 1, pp. 73-83. DOI: https://doi.org/10.31866/2616745x.1.2018.133416.

(С) Лікарчук Д. С., 2019 